\title{
ANALISIS TRIWULANAN: \\ Perkembangan Moneter, Perbankan dan Sistem Pembayaran, Triwulan IV - 2006
}

Tim Penulis Laporan Triwulanan, Bank Indonesia

Secara umum, kinerja perekonomian Indonesia pada triwulan IV-2006 terus menunjukkan perkembangan yang membaik dan disertai dengan stabilitas makro yang terjaga. Pertumbuhan ekonomi pada triwulan ini diperkirakan akan menjadi pertumbuhan tertinggi dalam tahun 2006. Sementara itu, beberapa indikator makro juga menunjukkan perkembangan yang positif seperti neraca pembayaran yang surplus, nilai tukar yang menguat, dan inflasi yang terus menurun. Hal tersebut juga didukung oleh sektor keuangan yang relatif stabil seperti terlihat pada perkembangan pasar saham, pasar modal, dan pasar uang. Dengan perkembangan tersebut serta dengan memperhatikan prospek ekonomi moneter ke depan dan berbagai faktor risiko yang dihadapi serta memperhatikan pencapaian sasaran inflasi ke depan yaitu 6\% $1 \%$ dan 5\% $1 \%$ untuk masing-masing tahun 2007 dan 2008, Dewan Gubernur BI pada tanggal 4 Januari 2007, memutuskan untuk menurunkan BI Rate menjadi 9,5\% atau turun 25 basis poin (bps) dari tingkat sebelumnya.

Pada triwulan IV-2006, pertumbuhan ekonomi diperkirakan sebesar 6,5\% (yoy), lebih baik dibandingkan dengan tiga triwulan sebelumnya. Dengan pertumbuhan tersebut maka secara keseluruhan tahun 2006 pertumbuhan ekonomi diperkirakan sebesar 5,5\%. Pertumbuhan ekonomi tersebut terutama didorong oleh kinerja ekspor yang masih tinggi dan peningkatan konsumsi. Selain itu, pertumbuhan tersebut juga ditandai oleh peningkatan investasi meskipun masih terbatas. Secara sektoral, hampir seluruh sektor mencatat peningkatan. Namun demikian, kontribusi pertumbuhan ekonomi terutama berasal dari sektor perdagangan, hotel dan restoran serta sektor industri pengolahan.

Membaiknya kinerja ekspor memberi kontribusi yang besar terhadap surplus Neraca Pembayaran Indonesia (NPI). NPI triwulan IV-2006 mencatat surplus cukup tinggi, terutama dipengaruhi oleh surplus di neraca transaksi berjalan. Surplus transaksi berjalan terutama didorong oleh tingginya pertumbuhan ekspor nonmigas sejalan dengan masih kuatnya permintaan dunia dan tingginya harga komoditas di pasar internasional. Sementara itu, pertumbuhan impor relatif tetap sejalan dengan masih rendahnya permintaan domestik. Di sisi 
neraca lalu lintas modal dan finansial mencatat defisit, yang antara lain disebabkan oleh aliran uang keluar (outflow) akibat peningkatan penempatan residen ke perbankan di luar negeri. Namun demikian, aliran portfolio investment masih tinggi tercermin pada peningkatan kepemilikan asing pada surat-surat berharga seperti SBI dan saham. Dengan surplus transaksi berjalan yang cukup, secara keseluruhan, kondisi tersebut meningkatkan jumlah cadangan devisa menjadi sekitar USD 42,4 miliar atau sekitar 4,6 bulan impor dan pembayaran utang luar negeri pemerintah. Jumlah tersebut meningkat dibandingkan dengan tahun lalu.

Kondisi NPI yang membaik, terjaganya imbal hasil dan membaiknya faktor risiko berdampak positif terhadap kestabilan nilai tukar rupiah sepanjang periode laporan. Pada triwulan ini, secara point to point rupiah ditutup menguat ke level Rp 8.995 dibandingkan dengan triwulan sebelumnya yang mencapai Rp 9.225. Penguatan tersebut juga disertai dengan tingkat stabilitas nilai tukar yang lebih baik tercermin dari volatilitas yang menurun menjadi $0,46 \%$ dari $0,85 \%$ pada triwulan sebelumnya.

Seiring dengan relatif stabilnya pergerakan rupiah, sampai pada akhir Desember 2006, inflasi tetap terkendali dan terus dalam kecenderungan menurun. Secara tahunan, inflasi IHK pada akhir tahun 2006 mencapai 6,60\% (y-o-y), turun tajam dari 17,11 (y-o-y) pada tahun 2005. Dengan demikian, inflasi yang telah dicapai tersebut lebih rendah dari sasaran yang ditetapkan yaitu $8,0 \% \pm 1 \%$. Sementara itu, inflasi inti dan inflasi administered juga menurun. Secara tahunan, inflasi inti tercatat sebesar 6,03\% (y-o-y), turun dari triwulan sebelumnya sejalan dengan perkembangan faktor-faktor fundamental yang terjaga.

Sejalan dengan kestabilan makro yang dicapai dan terjaganya inflasi dalam kisaran sasarannya, Bank Indonesia terus menurunkan suku bunga BI Rate. Selama triwulan ini, BI Rate sudah diturunkan 3 kali dengan total penurunan sebesar 150 bps sehingga menjadi 9,75\%. Berlanjutnya penurunan suku bunga ini direspon positif pelaku pasar dan disambut baik dunia usaha. Hal tersebut tercermin dari terus meningkatnya harga saham dan akhirnya ditutup pada level 1.805, menurunnya suku bunga jangka panjang (yield obligasi), dan mulai tumbuhnya keyakinan konsumen. Namun, penurunan BI Rate masih ditransmisikan secara terbatas ke suku bunga kredit.

Ke depan, Bank Indonesia optimis bahwa perekonomian Indonesia pada tahun 2007 akan mencatat pertumbuhan yang lebih tinggi dan disertai terjaganya stabilitas makroekonomi. Pertumbuhan ekonomi 2007 diprakirakan mencapai 5,7-6,3\% atau lebih tinggi dari pertumbuhan ekonomi 2006 yang diperkirakan mencapai 5,5\%. Pada semester I-2007, peningkatan pertumbuhan ekonomi 2007 terutama didorong oleh konsumsi sedangkan investasi swasta belum meningkat secara berarti. Akselerasi pertumbuhan ekonomi diperkirakan akan semakin kuat pada semester II-2007 sejalan dengan meningkatnya investasi swasta dan peningkatan yang semakin besar pada belanja modal pemerintah. Dari sisi fiskal, pengeluaran 
pemerintah yang tepat waktu dan tepat sasaran diharapkan dapat memberikan stimulus terhadap pertumbuhan ekonomi secara efektif. Di sisi eksternal, kegiatan ekspor diperkirakan masih tumbuh tinggi meski cenderung melambat akibat pertumbuhan ekonomi dunia yang tidak sekuat tahun 2006. Sementara itu, kegiatan impor barang dan jasa diperkirakan mengalami peningkatan sejalan dengan peningkatan permintaan domestik. Kondisi ini diperkirakan mempengaruhi kinerja neraca pembayaran 2007 yang diperkirakan masih mencatat surplus sehingga mendukung relatif stabilnya pergerakan nilai tukar rupiah.

Peningkatan kegiatan ekonomi diperkirakan tidak memberikan tekanan berlebihan terhadap harga-harga secara umum. Inflasi IHK pada 2007 diperkirakan masih dalam kisaran sasaran yang ditetapkan Pemerintah sebesar $6 \pm 1 \%$. Peningkatan permintaan yang sejalan dengan perkiraan peningkatan pertumbuhan ekonomi masih dapat diimbangi perbaikan sisi penawaran sehingga tidak banyak memberikan tekanan terhadap inflasi inti. Prakiraan inflasi IHK 2007 juga didukung rendahnya tekanan kenaikan harga komponen administered (harga yang dikendalikan pemerintah) sejalan dengan tidak adanya rencana pemerintah untuk meningkatkan harga kelompok barang administered strategis. Di samping itu, tekanan inflasi kelompok volatile foods juga diperkirakan tetap rendah sejalan komitmen pemerintah dalam menjaga kelancaran pasokan makanan khususnya barang-barang kebutuhan pokok.

Di tengah berbagai perkembangan positif tersebut, Bank Indonesia memandang masih terdapat beberapa faktor risiko, baik dari eksternal maupun internal, yang dapat mengganggu perekonomian 2007. Dari sisi eksternal risiko yang akan senantiasa menjadi perhatian Bank Indonesia adalah kemungkinan ekonomi global yang tumbuh rendah dan perubahan preferensi investasi global. Sementara itu, dari sisi internal permasalahan struktural seperti masih terkendalanya implementasi paket iklim investasi, infrastuktur, dan keuangan merupakan faktor risiko yang perlu dicermati di samping permasalahan lain seperti kemungkinan gangguan dan pasokan distribusi domestik dan kemungkinan bubble di pasar modal. Apabila faktor risiko di atas dapat diatasi dengan baik maka pertumbuhan ekonomi pada tahun 2007 akan dapat tumbuh lebih tinggi dari yang diperkirakan.

Mempertimbangkan kondisi obyektif perkiraan ekonomi 2007 tersebut, Bank Indonesia berpandangan bahwa kerja keras dan jalinan koordinasi yang erat dari lembaga terkait perlu terus ditingkatkan baik pada tataran kebijakan maupun implementasinya di lapangan. Demikian pula peran aktif segenap pelaku ekonomi sangat dibutuhkan untuk mencapai pertumbuhan ekonomi yang lebih tinggi dan berkualitas. Dari sisi moneter, kebijakan moneter akan terus diarahkan untuk menciptakan stabilitas makroekonomi guna mendukung kesinambungan pertumbuhan ekonomi. Di bidang perbankan, Bank Indonesia akan terus berupaya untuk meningkatkan fungsi intermediasi perbankan agar dapat memenuhi kebutuhan pembiayaan bagi dunia usaha secara efektif. 
